\title{
A Di Copper Peptidyl Complex Mimics Catalase Activity in HeLa HyPer Cells
}

\author{
Koudedja Coulibaly, ${ }^{\mathrm{a}}$ Marion Thauvin,${ }^{\mathrm{b}, \mathrm{c}}$ Adyn Melenbacher, ${ }^{\mathrm{d}}$ Clara Testard, ${ }^{\mathrm{a}}$ Evangelia Trigoni, ${ }^{\mathrm{a}}$ Amandine Vincent, ${ }^{\mathrm{a}}$ Martin J. \\ Stillman, ${ }^{d}$ Sophie Vriz, ${ }^{\text {be }}$ Clotilde Policar ${ }^{a}$ and Nicolas Delsuc*a \\ a. Laboratoire des biomolécules, LBM, Département de chimie, Ecole Normale Supérieure, PSL University, Sorbonne Université, CNRS, 75005 Paris, France. E-mail: \\ nicolas.delsuc@ens.psl.eu \\ b. Centre Interdisciplinaire de Recherche en Biologie (CIRB), CNRS UMR7241/INSERM U1050/Collège de France, 75231 Paris, Cedex 05, France. \\ c. Sorbonne Université, 4 place Jussieu, 75005, Paris, France. \\ d. Department of Chemistry, The University of Western Ontario, London, ON N6A 5B7, Canada. \\ e. Université de Paris, Faculty of Science - 75006 Paris, France.
}

\begin{abstract}
Catalases (CAT) are antioxidant metalloenzymes necessary for life in oxygen-metabolizing cells to regulate $\mathrm{H}_{2} \mathrm{O}_{2}$ concentration by accelerating its dismutation. Many physio-pathological situations are associated with oxidative stress resulting from $\mathrm{H}_{2} \mathrm{O}_{2}$ overproduction during which antioxidant defenses are overwhelmed. We have used a combinatorial approach associated with an activity-based screening to discover a first peptidyl di copper complex mimicking CAT. The complex was studied in detail and characterized for its CAT activity both in vitro and in cells using different analytical methods. The complex exhibited CAT activity in vitro and, more interestingly, on HyPer HeLa cells which possess a genetically encoded ratiometric fluorescent sensors of $\mathrm{H}_{2} \mathrm{O}_{2}$. These results highlight the efficiency of a combinatorial approach for the discovery of peptidyl complexes that exhibit catalytic activity.
\end{abstract}

\section{Introduction}

Aerobic organisms generate their energy through the reduction of $\mathrm{O}_{2}$ to $\mathrm{H}_{2} \mathrm{O}$. During this process, reactive oxygen species (ROS) are continuously formed. The redox cascade initially forming $\mathrm{O}_{2} \cdot$ - leads to the subsequent formation of $\mathrm{H}_{2} \mathrm{O}_{2}$, a second ROS. $\mathrm{H}_{2} \mathrm{O}_{2}$ then dissociates to the hydroxyl radical $(\bullet \mathrm{OH})$ in mitochondria and/or peroxisomes. ROS play a key role in a range of different mechanisms such as cell proliferation and cell differentiation. ${ }^{1-3}$ ROS are very reactive molecules with strongly oxidizing properties. The most reactive and damaging is $\bullet \mathrm{OH}$. Although $\mathrm{H}_{2} \mathrm{O}_{2}$ and $\mathrm{O}_{2}{ }^{*}$ are not as reactive, they can become cytotoxic if their intracellular concentration exceeds a limiting threshold, overwhelming the protective pathways and leading to oxidative stress. Indeed, under oxidative stress, the uncontrolled oxidation of biomolecules such as lipids, proteins, or DNA can occur inducing cell damage and/or death. ${ }^{4}$ Oxidative stress is thus implicated in many physio-pathological situations such as neurodegenerative diseases (Parkinson's disease and Alzheimer's disease) ${ }^{5}$ chronic inflammatory diseases, chronic obstructive pulmonary diseases (COPD), ${ }^{6,7}$ chronic kidney diseases (CKD), ${ }^{8-10}$ metabolic diseases (diabetes), ${ }^{11,12}$ or cancers. ${ }^{13,14}$ Although the presence of ROS is not always the sole cause of these different diseases, it, nevertheless, is a major contributor. It is, therefore, essential to control ROS concentration in order to limit their deleterious effects. Antioxidant defences protect biological systems from free radical toxicity and prevent damage due to excessive concentrations of ROS. This can be achieved either by controlling the reduction of ROS and/or by controlling the elimination of ROS. Antioxidants may either be synthesized by the cell or obtained through the diet. Cellular antioxidants such as glutathione (GSH), CoQ10 ubiquinol and those obtained through the $\operatorname{diet}^{15}$ (vitamins E and C, carotenoids, some polyphenols, essential oils, carnosine $)^{16}$ react stoichiometrically with the ROS. Another family of antioxidants includes metalloenzymes such as superoxide dismutase (SOD), ${ }^{17-23}$ catalase, ${ }^{24,25}$ glutathione peroxidase (GPx), and glutathione reductase. ${ }^{26,27}$ Unlike the small molecules referred to above, these metalloenzymes react catalytically with ROS to transform them into less toxic cellular species. ${ }^{28}$

Despite the fact that higher concentrations of $\mathrm{H}_{2} \mathrm{O}_{2}$ than $\mathrm{O}_{2}{ }^{-*}$ or $\mathrm{OH} \bullet$ are tolerated in cells, the intracellular concentrations of $\mathrm{H}_{2} \mathrm{O}_{2}$ must be tightly controlled at 1-100 nM. ${ }^{3}$ Indeed, through the Fenton or Haber-Weiss reaction or in the presence of chloride and myeloperoxidase (MPO), $\mathrm{H}_{2} \mathrm{O}_{2}$ is able to form the hydroxyl radical ion and hypochlorous acid, respectively, which are much more toxic. ${ }^{29}$ CAT is one of the enzymes involved in the regulation of $\mathrm{H}_{2} \mathrm{O}_{2}$ concentration by accelerating its dismutation, which is thermodynamically favorable but kinetically slow. ${ }^{30}$ During this reaction, a molecule of $\mathrm{H}_{2} \mathrm{O}_{2}$ is reduced to two molecules of $\mathrm{H}_{2} \mathrm{O}$, and a second molecule of $\mathrm{H}_{2} \mathrm{O}_{2}$ is oxidized to $\mathrm{O}_{2} \cdot{ }^{31}$ CAT is present in all aerobic species: archaea, bacteria, fungi, plants, and animals including humans. ${ }^{25}$ To date, two classes of catalase have been identified: a monofunctional heme CAT (HemeCAT), and a non-heme dinuclear manganese CAT (MnCAT). ${ }^{30-33}$ HemeCAT is found in the majority of aerobic prokaryotes, eukaryotes, and some anaerobes and is located in different cellular compartments including the cytosol, mitochondria and peroxisomes. HemeCAT is a heme enzyme existing in a tetrameric quaternary structure that forms a $20 \AA$ long channel making the active site accessible to substrates. The dismutation catalyzed by HemeCAT is carried out according to a ping-pong mechanism with a catalytic constant of $410^{7} \mathrm{M}^{-1} \cdot \mathrm{s}^{-1}$. The dismutation of $\mathrm{H}_{2} \mathrm{O}_{2}$ consists of two bi-electronic processes, requiring a bielectronic catalyst. In the case of the HemeCAT, the iron and porphyrin ligand both participate to the two electron exchanges, cycling between an (P)Fe $\mathrm{Fe}^{\mathrm{Ill}}$ resting state and $\mathrm{a}(\mathrm{P} \bullet+) \mathrm{Fe}^{\mathrm{IV}}=\mathrm{O}$ high oxidation state, (also called compound I). ${ }^{34,35}$ Three amino acids play a key role in catalyzing the dismutation of $\mathrm{H}_{2} \mathrm{O}_{2}$ : two distal residues, a histidine and an asparagine, which are involved in $\mathrm{H}_{2} \mathrm{O}_{2}$ stabilization in the active site, and one proximal tyrosine, which 
is directly bonded to the heme iron. A mutation of any one of these amino acids induces the total loss of enzymatic activity. ${ }^{31,36,37}$ MnCAT was more recently discovered in lactic acid bacteria, L. plantarum, ${ }^{33}$ T. thermophilus, ${ }^{38}$ and T. album. ${ }^{39}$, which lack heme and cytochrome. It has been demonstrated that MnCAT possesses a binuclear manganese active site which cycles between the reduced state $\mathrm{Mn}^{\mathrm{II}}-\mathrm{Mn}^{\|}$and the oxidized

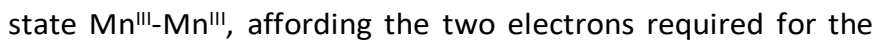
dismutation reaction. ${ }^{30,32,33}$

Small molecular complexes mimicking CAT have been developed to reduce oxidative stress in particular, in pathological conditions. ${ }^{40-45}$ These bioinspired mimics are thus mainly mononuclear ( $\mathrm{Mn}$ or $\mathrm{Fe}$ ) porphyrin derivatives or dinuclear manganese complexes analogous to the active site of HemeCAT or MnCAT, respectively. ${ }^{46}$ It has been proposed that for $\mathrm{Mn}$ porphyrin $(\mathrm{MnP})$, the catalysis occurs via the redox couples $\mathrm{Mn}^{\prime \prime \prime}(\mathrm{P}) /(\mathrm{O}){ }_{2} \mathrm{MnV}(\mathrm{P})$ or $\mathrm{Mn}^{\prime \prime}(\mathrm{P}) / \mathrm{O}=\mathrm{Mn}^{\mathrm{IV}}(\mathrm{P}) .{ }^{46}$ In this situation, the porphyrin can accommodate the metal cation with different redox states. A number of non-porphyrin mononuclear complexes such as salen derivatives, corroles, macrocyclic, and polyamines are described as CAT mimics although these ligands may not be able to stabilize the corresponding metal ion with oxidation states varying from $\mathrm{M}^{\mathrm{n}+}$ to $\mathrm{M}^{(\mathrm{n}+2)+}$ during the catalysis. When mechanistic studies were performed, it appeared that rapid dimerization of these compounds was observed in solution, to provide the required two electrons without reaching the high oxidation state of a single complex. ${ }^{47}$ However, under the conditions of the catalase assay, these dimers lose their activity within a few minutes. ${ }^{48}$ Dinuclear $\mathrm{Mn}$ complexes bioinspired from MnCAT are mainly alkoxo, phenoxo, or oxo/carboxylato bridged complexes. In an excellent review, Signorella and Hureau have reported that besides the redox potentials of the metal ions key to catalytic $\mathrm{H}_{2} \mathrm{O}_{2}$ dismutation, the efficacy of the complexes is associated with the presence of an intramolecular base to assist in deprotonation. In addition, the presence of a vacant site on the $\mathrm{Mn}$ ion is required to coordinate $\mathrm{H}_{2} \mathrm{O}_{2}$, but the complex stability is reduced by the protonation of the bridging ligand. 48
The requirement of a bi-electronic process involves designing CAT mimics with two redox centres that can be achieved by a metal and an oxidizable ligand, such as porphyrins, or by the presence of two metal centres. This is different than what is required for mimics of monoelectronic catalysts, such as superoxide dismutase (SOD). Whereas peptidyl SOD mimics have been studied, ${ }^{49-52}$ no peptidyl catalase mimics have been reported so far, which may be explained by the difficulty to rationally design a peptide able to bind two metal cations with appropriate redox potentials and affinities. ${ }^{48,53-55}$

In this manuscript, we describe implementation of a combinatorial approach to synthesize a library of copper complexes, associated with an activity-based screening to discover the first peptidyl di copper complex mimicking CAT redox chemistry. The selected dinuclear copper complex was studied in detail and characterized for its CAT activity in vitro and in cells. Very interestingly, despite moderate intrinsic catalysis constants, this complex was efficacious in a cellular assay.

\section{Results and discussion}

To generate a large number of small peptidyl metal complexes, a peptide library was synthesized on a solid support by a splitand-pool combinatorial method leading to a one-bead-onepeptide library (Scheme S1). Inspired by the method developed by B. Imperiali who discovered a lanthanide binding tag ${ }^{56}$ which we have recently implemented for the discovery of peptidyl SOD mimics efficient in cells, ${ }^{52}$ the peptide library was designed to generate peptides that strongly bind copper. Peptides of the library have a general sequence $A c-\mathrm{PX}_{2} \mathrm{X}_{3} \mathrm{KHX} \mathrm{X}_{6} \mathrm{LH}-\mathrm{OH}$ where $\mathrm{X}$ indicates places where diversity was introduced. Amino acids possessing coordinating side chains (aspartate or glutamate, tyrosine and histidine) and non-coordinating side chains (glycine and arginine) at positions $X_{n}$ were chosen to explore the properties of the $5^{3}$ peptides (Fig. 1A).

A
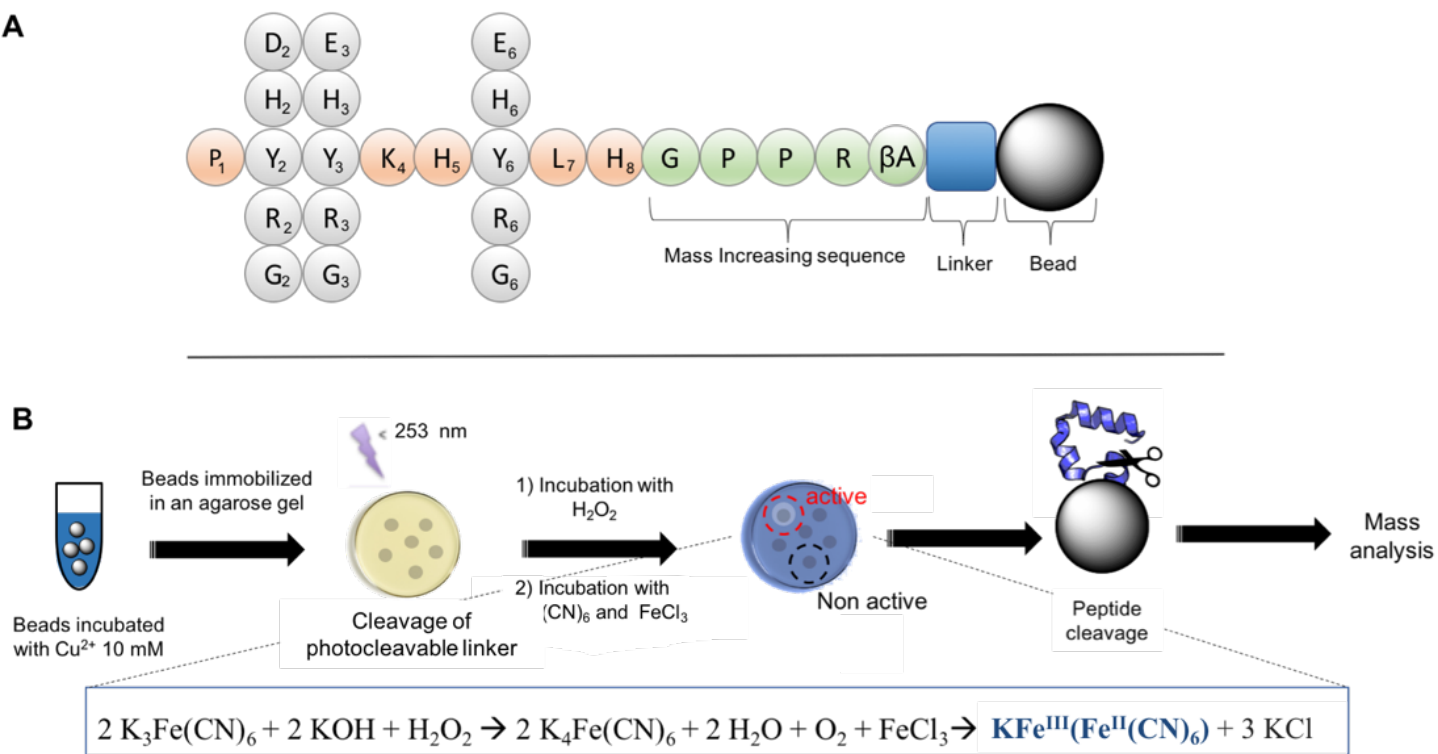

Fig. 1 (A) Peptide library on bead. Beads are Tentagel macrobeads. Two linkers were introduced: $10 \%$ of 4-nitrophenylalanine cleaved under UV irradiation and 90\% of 4 (hydroxymethyl)benzoic acid (HMBA) cleaved in basic conditions. (B) Scheme of peptidyl complexes screening using a colorimetric activity-based assay. 
After side chain deprotection using trifluoroacetic acid, the supported peptides were incubated in a solution of $\mathrm{CuSO}_{4}(10$ $\mathrm{mM}$ ) in HEPES buffer ( $50 \mathrm{mM}, \mathrm{pH} 7.5)$ for $2 \mathrm{hr}$. The beads were then washed with buffer and EDTA ( $25 \mathrm{mM}, \mathrm{pH} 8)$, a strong competitor $^{57}$ for $\mathrm{Cu}$ (II) chelation, to increase differential selectivity. This additional washing step allows for the removal of more loosely bound copper ions and/or the release of copper from less inert complexes. However, this step does not ensure that the remaining complexes are more stable or inert than the EDTA-Cu complex since it is a heterogenous process. To perform the screening of the peptidyl complexes library, the beads carrying the peptidyl complexes were immobilized in a $2 \%$ agarose gel according to the method developed by Nitz et al. (Fig. 1B). ${ }^{56}$ The gel was then irradiated using UV light (254 nm) for 15 minutes to release the portion of peptidyl complexes that were linked to the resin via a photocleavable linker (ca.10\%, Fig. 1A). The diffusion of the complexes from the bead within the gel increased their accessibility and the surface area where the potential CAT mimics are present. To screen the peptidyl metal catalysts according to their CAT activity, a protocol inspired from the functional assay used to characterize CAT on electrophoretic gels was implemented. ${ }^{58}$ The gel was incubated with a solution of $\mathrm{H}_{2} \mathrm{O}_{2}(0.015 \%)$ for $10 \mathrm{~min}$ and subsequently with two ferric complexes, $\mathrm{K}_{3} \mathrm{Fe}(\mathrm{CN})_{6}$ and $\mathrm{FeCl}_{3}$. In the presence of $\mathrm{H}_{2} \mathrm{O}_{2}, \mathrm{~K}_{3} \mathrm{Fe}(\mathrm{CN})_{6}$, an orange-yellow solution, is reduced to $\mathrm{K}_{4} \mathrm{Fe}(\mathrm{CN})_{6}$, which then reacts with $\mathrm{FeCl}_{3}$ to give Prussian blue $\left(\mathrm{K}_{3} \mathrm{Fe}^{\prime \prime \prime}\left(\mathrm{Fe}^{\prime \prime}(\mathrm{CN})_{6}\right)\right)$, which has a deep blue color. ${ }^{58}$ The medium around the bead is depleted in $\mathrm{H}_{2} \mathrm{O}_{2}$ when a CAT mimic is present, because of the fast dismutation of $\mathrm{H}_{2} \mathrm{O}_{2}$. This prevents the reduction of $\mathrm{K}_{3} \mathrm{Fe}(\mathrm{CN})_{6}$ and the formation of Prussian blue. A colorless area around the bead thus indicates that an active CAT mimic is present. It is worth mentioning that when the beads were not incubated in the copper solution, no positive results were obtained. This supports the fact that if iron complexes were formed from the $\mathrm{K}_{3} \mathrm{Fe}(\mathrm{CN})_{6}$ and $\mathrm{FeCl}_{3}$, they are not active for $\mathrm{H}_{2} \mathrm{O}_{2}$ dismutation. Using this procedure, sixteen beads from the pool of 600 tested were selected, removed from the gel, and extensively washed with EDTA to eliminate the copper. The peptides were then cleaved from the resin and analyzed by MALDI-TOF mass spectrometry (Fig. 1B). To enable the unambiguous elucidation of the peptide sequence using a single mass spectrometric analysis, the method developed by Griesinger et al., ${ }^{59}$ adapted by Imperiali et al. ${ }^{56}$ which we used previously ${ }^{2}$ was employed (Fig. S1). Among the sixteen beads collected, the primary sequence could be determined for twelve peptides (Table S1, A). Interestingly, at positions $X_{2}$ and $X_{3}$, coordinating amino acids were mainly found with histidine being the more often observed amino acid at position $X_{2}$ and tyrosine at position $X_{3}$. On the contrary, at position $X_{6}$ noncoordinating amino acids were mainly observed (Table S1, B). Importantly, the peptide sequence PHYKHRLH (called CATm1) was found twice and a third, with a sequence (PHYKHGLH) that differs only by the non-coordinating amino acid at position $\mathrm{X}_{6}$ was also found. CATm1 was selected for further investigations. The CATm1- $\mathrm{Cu}^{2+}$ complex was first investigated in solution in a MOPS buffer ( $50 \mathrm{mM}$ ), a fairly low complexing buffer, at $\mathrm{pH} 7.5$ by Electron Paramagnetic Resonance (EPR) spectroscopy. Frozen solutions with different CATm1: $\mathrm{Cu}^{2+}$ ratios ranging from
1:0.5 to 1:5 were prepared and recorded at low temperature ( $T$ $=110 \mathrm{~K})$.
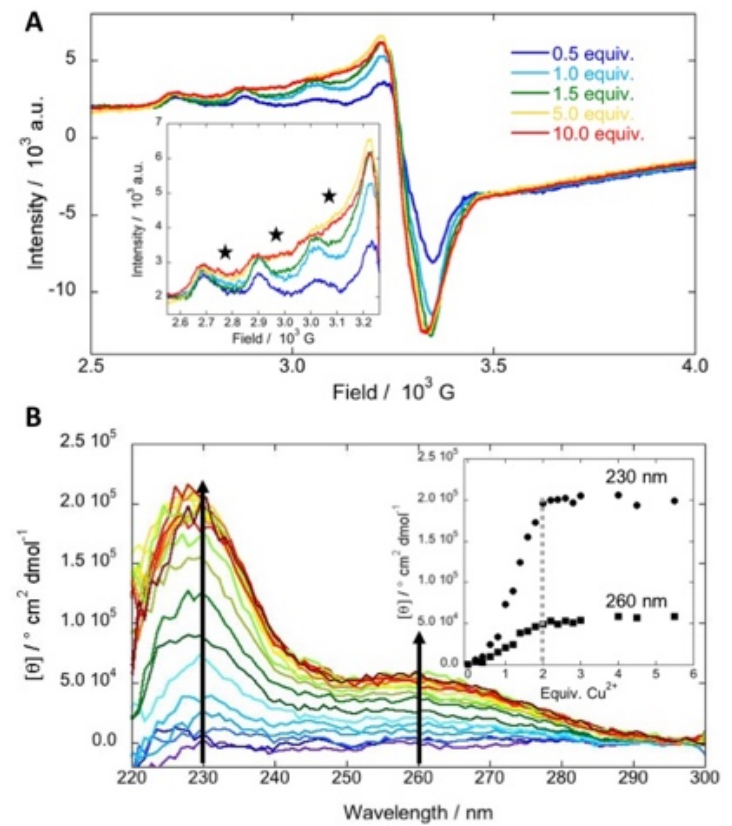

Fig. 2 (A) Electron Paramagnetic Resonance spectra in MOPS buffer (50 mM, pH 7.5, $25^{\circ} \mathrm{C}$, glycerol $10 \%$ ) of a mixture CATm1: $\mathrm{Cu}^{2+}$ at different ratios, [CATm1] $=20 \mu \mathrm{M}$, $\mathrm{T}=110 \mathrm{~K}$. The inset shows a zoom with the new set of signals indicated with stars (B) CATm1 titration with $\mathrm{Cu}^{2+}$ by UV-vis circular dichroism in MOPS buffer $(50 \mathrm{mM}, \mathrm{pH} 7.5$, $\left.25^{\circ} \mathrm{C}\right),[\mathrm{CATm} 1]=200 \mu \mathrm{M}, \mathrm{T}=25^{\circ} \mathrm{C}$. The inset shows the evolution of the two maxima at 230 and $260 \mathrm{~nm}$ upon $\mathrm{Cu}^{2+}$ addition. The plateau is reached after two equivalents of $\mathrm{Cu}^{2+}$.

The EPR spectrum obtained in the presence of 0.5 equivalent of $\mathrm{Cu}^{2+}$, where the observed parameters were $\mathrm{g} / /=2.26>\mathrm{g} \perp=2.06$ and $\mathrm{A} / /$ $=0.178 \mathrm{~cm}^{-1}$, indicates a square planar geometry (Fig. $2 \mathrm{~A}$ ). ${ }^{60-62}$ This spectrum suggests a coordination site very similar to the copper coordination site of an Imidazoyl N4 ligand.63,64 Upon addition of $\mathrm{Cu}^{2+}$, the intensity of the signal increased and a second set of signals appeared gradually. This suggests that a first complex may be formed and that above one equivalent, a second copper ion is also bound (Fig. 2A). A titration performed in MOPS buffer ( $50 \mathrm{mM}, \mathrm{pH} 7.5)$ by UV-vis circular dichroism spectroscopy confirmed this hypothesis: upon addition of $\mathrm{Cu}^{2+}$, the bands at $230 \mathrm{~nm}$ and at $260 \mathrm{~nm}$ increased up to two equivalents and reached a plateau (Fig. 2B).

The key parameter in efficiently catalysing $\mathrm{H}_{2} \mathrm{O}_{2}$ dismutation is the two-electron redox potential of the CAT. The redox potential must lie between the potentials of the $\mathrm{O}_{2} / \mathrm{H}_{2} \mathrm{O}_{2}$ and $\mathrm{H}_{2} \mathrm{O}_{2} / \mathrm{H}_{2} \mathrm{O}$ couples that are $0.28 \mathrm{~V}$ and $1.35 \mathrm{~V}$ vs. NHE, respectively. ${ }^{47}$ The CATm1-Cu ${ }^{2+}$ complex was examined by cyclic voltammetry in a MOPS buffer $(50 \mathrm{mM})$ at $\mathrm{pH} 7.5$. For a $1: 1$ CATm1:Cu(II) ratio, the mixture exhibited anodic and cathodic potentials that differ from those of $\mathrm{Cu}^{2+}$ and CATm1 in solution, providing evidence that at least one complex is formed (Fig. 3A). A titration was performed by electrochemistry (Fig. 3B). Upon addition of $\mathrm{Cu}^{2+}$, the current corresponding to the anodic potential (at ca. $0.5 \mathrm{~V}$ vs. NHE) increased linearly up to 2 equivalents (Fig. $3 \mathrm{C}$ left). Interestingly, after 2 equivalents, the slope was modified (Fig. 3C), showing that after a 1:2 ratio, the system behaved differently. In addition, above the $1: 2$ ratio, the current at the potential corresponding to anodic re-dissolution of $\mathrm{Cu}^{0}$ adsorbed onto the electrode appeared at $c a .0 .24 \mathrm{~V} / \mathrm{NHE}$, 
highlighting the fact that the peptide was unable to bind more than two copper cations (Fig. 3B yellow to red). The titration was also performed in TRIS buffer (50 mM, pH 7.5), which is considered to bind copper with a higher affinity than MOPS buffer. ${ }^{65,66}$ Interestingly, the same trend was observed except that the peak corresponding to the anodic redissolution appeared before 2 equivalents, probably because of the presence of a TRIS-Cu complex (Fig. S4). All together these results suggest that at $\mathrm{pH} 7.5$, CATm 1 is able to bind 2 copper(II) cations with an affinity for the second copper ion that is lower than for the first one. The reduction and oxidation potentials of the complex were measured at $0.14 \mathrm{~V} / \mathrm{NHE}$ and $0.5 \mathrm{~V} / \mathrm{NHE}$, respectively, and are thus in the correct range to catalyze $\mathrm{H}_{2} \mathrm{O}_{2}$ dismutation. In the same way, the titration performed by cyclic voltammetry at $\mathrm{pH} 7.0$ in MOPS buffer $(50 \mathrm{mM})$ indicated that, at this $\mathrm{pH}$, a 1:2 complex was also formed with a second site showing a weaker affinity constant (Fig. S5).

A
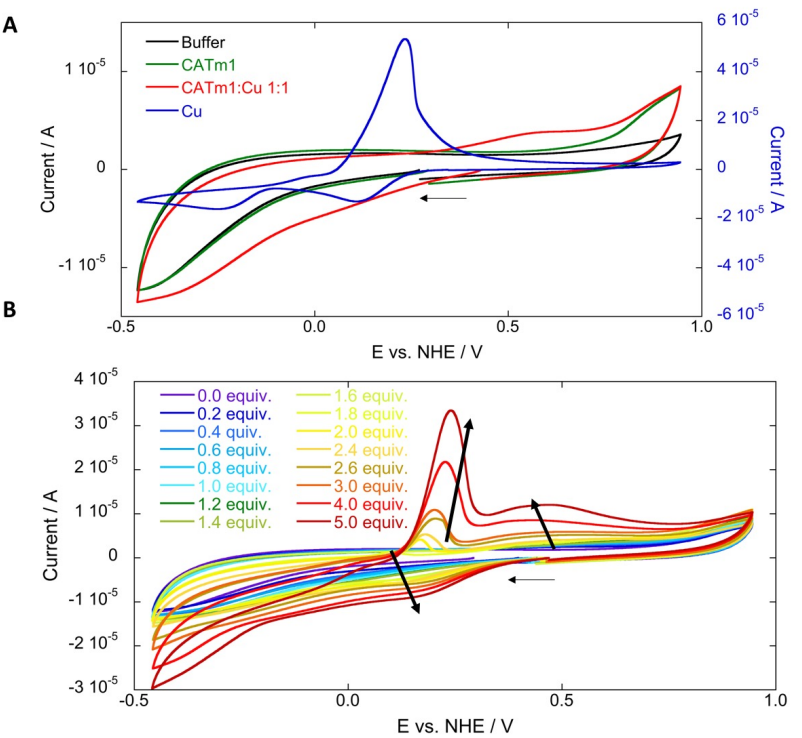

C
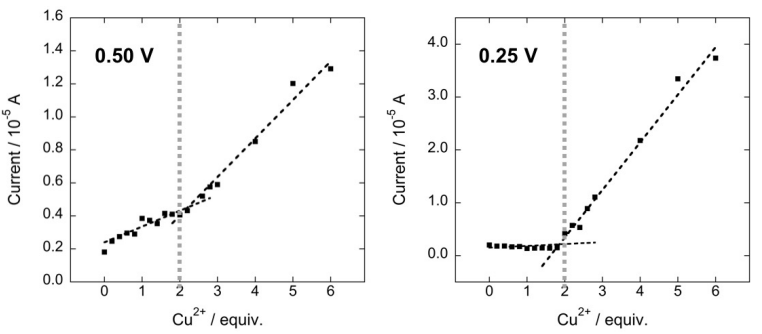

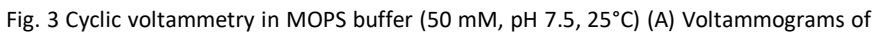
CATm1 (1 mM), CATm1:Cu ${ }^{2+} 1: 1(1 \mathrm{mM})$ and $\mathrm{Cu}(\mathrm{OAC})_{2}(1 \mathrm{mM}$ in TRIS buffer, $50 \mathrm{mM}, \mathrm{pH}$ 7.5); (B) Titration of CATm1 (1 mM) by $\mathrm{Cu}(\mathrm{OAC})_{2}$ (C) Evolution of the current at the anodic potential $0.5 \mathrm{~V}$ vs NHE (left) and at the potential corresponding to the anodic redissolution (0.24 V, right). Working electrode: Glassy carbon ( $3 \mathrm{~mm}$ diameter), counter electrode: Platinum, reference electrode: SCE. Scan rate of $100 \mathrm{mV} / \mathrm{s}$, the small arrow indicates the scanning direction and arrows in bold, the evolution of the waves upon addition of $\mathrm{Cu}(\mathrm{OAc})_{2}$.

In order to obtain further insight into the stability of this $1: 2$ complex, the apparent dissociation constants were determined by isothermal titration calorimetry (ITC) at pH 7 and 7.5 in MOPS buffer $(50 \mathrm{mM})$. At $\mathrm{pH} 7$, the thermogram obtained was successfully fitted with a " 2 independent sites" model leading to apparent dissociation constants of about $\mathrm{K}_{\mathrm{d} 1}=2.3410^{-7}$ and $\mathrm{K}_{\mathrm{d} 2}=3.6210^{-6}$, thus confirming that the peptide is able to bind two copper(II) ions with a second site exhibiting a weaker affinity constant (Fig. S6, Table 1). The first complexion reaction has a large favorable enthalpic component $\left(\Delta \mathrm{H}_{1}=-47.49 \mathrm{~kJ} \mathrm{~mol}^{-}\right.$ $\left.{ }^{1}\right)$ and an unfavorable entropic component $\left(-\mathrm{T} \Delta \mathrm{S}_{1}=10.7 \mathrm{~kJ} \mathrm{~mol}^{-}\right.$ $\left.{ }^{1}\right)$, whereas it is the opposite for the second site $\left(\Delta \mathrm{H}_{2}=11.02 \mathrm{~kJ}\right.$ $\mathrm{mol}^{-1}$ and $-\mathrm{T} \Delta \mathrm{S}_{2}=-41.4 \mathrm{~kJ} \mathrm{~mol}^{-1}$ ) leading to overall Gibbs free energies of -36.8 and $-30.4 \mathrm{~kJ} \mathrm{~mol}^{-1}$ for the first and the second site, respectively. The first complexation reaction is more favorable than the second one which is entropically driven (Fig. S6, Table 1).

Table 1 Thermodynamic parameters for complexation of $\mathrm{Cu}(\mathrm{II})$ with CATm1 measured using ITC or mass spectrometry at $25^{\circ} \mathrm{C}$

\begin{tabular}{llcc}
\hline & & $\mathrm{pH} 7.0$ (MOPS) & $\mathrm{pH} \mathrm{7.5}\left(\mathrm{NH}_{4} \mathrm{HCO}_{2}\right)$ \\
\hline $1^{\text {st }}$ Site & $\mathrm{n}_{1}$ & $0.89 \pm 0.10$ & - \\
& $\Delta \mathrm{H}_{1}\left(\mathrm{~kJ} \mathrm{~mol}^{-1}\right)$ & -47.49 & - \\
& $\Delta \mathrm{S}_{1}\left(\mathrm{~J} \mathrm{~mol}^{-1} \mathrm{~K}^{-1}\right)$ & -35.74 & - \\
& $\mathrm{K}_{\mathrm{d} 1}$ & $2.3 \pm 1.710^{-7}$ & $1.1210^{-9[\mathrm{a}]}$ \\
$2^{\text {nd }}$ Site & $\mathrm{n}_{2}$ & $1.07 \pm 0.02$ & \\
& $\Delta \mathrm{H}_{2}\left(\mathrm{~kJ} \mathrm{~mol}^{-1}\right)$ & 11.02 & \\
& $\Delta \mathrm{S}_{2}\left(\mathrm{~J} \mathrm{~mol}^{-1} \mathrm{~K}^{-1}\right)$ & 138.80 & \\
& $\mathrm{~K}_{\mathrm{d} 2}$ & $3.6 \pm 1.610^{-6}$ & $4.5710^{-9[\mathrm{a}]}$ \\
\hline
\end{tabular}

[a] Apparent dissociation $\left(\mathrm{K}_{\mathrm{d}}\right)$ constants measured by ESI at $25^{\circ} \mathrm{C}$.

At $\mathrm{pH}$ 7.5, a copper(II) titration measured by ITC did not allow for the measurement of the binding constants of the two sites, probably because they are too high and the ITC method is not sensitive enough (Fig. S7). It has been recently shown that mass spectrometry can reliably and accurately provide both speciation and binding constants for non-covalent protein complexes and peptidyl or proteyl metal complexes. ${ }^{67-70}$ Consequently, a titration by electrospray ionization mass spectrometry (ESI-MS) was performed in ammonium formate (10 mM) at $\mathrm{pH} 7.5$ to obtain the binding constants. Upon addition of copper(II) acetate to a solution of CATm1 (20 $\mu \mathrm{M})$, complexes with two stoichiometries corresponding to CATm1:Cu 1:1 and 1:2 were identified. After each addition of $\mathrm{CU}(\mathrm{II})$, the ESI-mass spectrum was measured. Representative spectra are given in Fig. 4A. The relative abundances of CATm1, CATm1:Cu 1:1, and CATm1:Cu 1:2 were normalized at each step in the ESI-MS titration and the mole equivalents of $\mathrm{Cu}$ (II) bound were calculated from the mass spectra to generate the speciation as a function of $\mathrm{Cu}$ (II) added (Fig. 4B). The speciation curves obtained were simulated using Hyperquad Simulation and Speciation (HySS) to afford the stepwise apparent dissociation constants for the first copper(II) $\left(K_{d 1}\right)$ and the second copper(II) $\left(\mathrm{K}_{\mathrm{d} 2}\right)$ bound to the peptide. The corresponding apparent dissociation constants found were $1.1210^{-9}$ and 4.57 $10^{-9}$ for the first and second sites, respectively.

In order to determine the intrinsic catalase-like activity of the redox-active peptidyl complex derived from CATm1, $\mathrm{O}_{2}$ formation was monitored in solutions containing $\mathrm{H}_{2} \mathrm{O}_{2}$ and the catalyst. $\mathrm{O}_{2}$ was measured by polarography using a Clark-type electrode. ${ }^{46}$ This was performed at several CATm1:Cu(II) ratios, leading to apparent kinetic constants. The measurement of the initial rates $\mathrm{v}_{0}=k_{\text {cat }}$ [catalyst $]_{0}\left[\mathrm{H}_{2} \mathrm{O}_{2}\right]_{0}$, which can be written $\mathrm{v}_{0}$ $=k_{\text {obs }}$ [catalyst $]_{0}$ under pseudo first order conditions depending 
on the catalyst concentration, enabled the determination of $k_{\text {obs }}$. The dismutation reaction follows second order kinetics where $\Delta\left[\mathrm{H}_{2} \mathrm{O}_{2}\right]=2 \Delta\left[\mathrm{O}_{2}\right]$, thus $k_{\text {cat }}$ could be calculated using the determined $k_{o b s}$ to be $k_{c a t}=2 k_{o b s} /\left[\mathrm{H}_{2} \mathrm{O}_{2}\right]_{0}$ (Fig. S8). The measured $k_{\text {cat }}$ is 10 times greater for the 1:2 peptide: $\mathrm{Cu}^{2+}$ ratio than for the 1:1 ratio, which is consistent with the requirement of 2 electrons for the catalysis of $\mathrm{H}_{2} \mathrm{O}_{2}$ dismutation, each copper cation bringing one election (Table 2). The apparent $k_{\text {cat }}$ for the $1: 2$ complex represents $0.001 \%$ of CAT activity measured under the same conditions. This is consistent with the activities measured for manganese porphyrins ( $\mathrm{MnP}$ ), which range from $0.0004 \%$ to $0.006 \%$ of CAT activity, depending on the structure of the porphyrin. ${ }^{46}$

a)
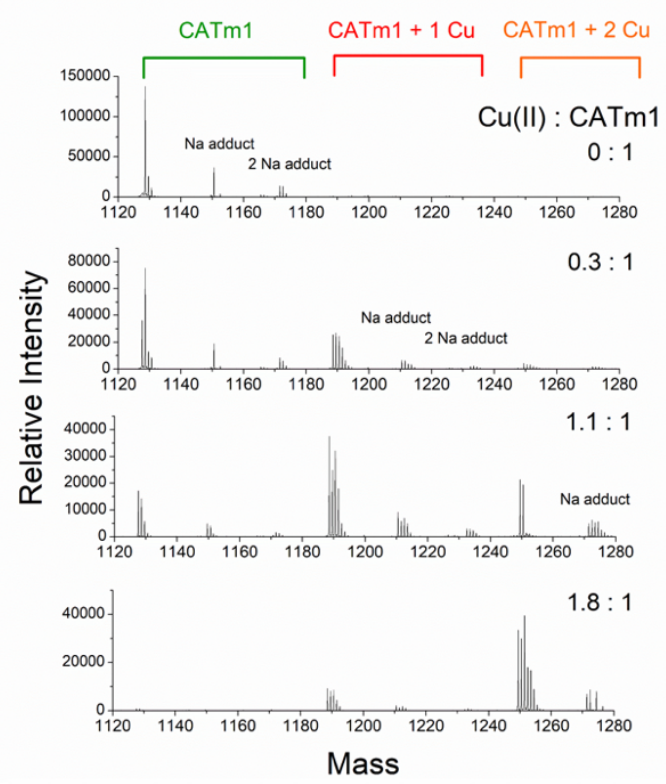

b)

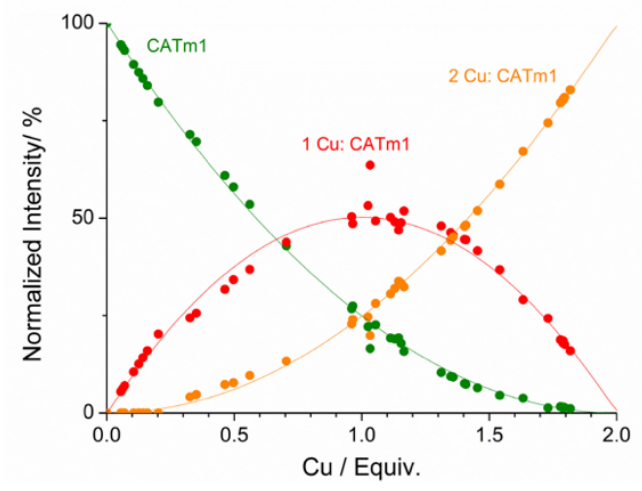

Fig. 4 Titration of CATm $1(20 \mu \mathrm{M})$ by copper acetate monitored by electrospray ionization mass spectrometry in ammonium formate $(10 \mathrm{mM})$ at $\mathrm{pH} 7.5$. a) Representative normalized spectra at ratio CATm1:Cu(II) 1:0, 1:0.3, 1:1.1, 1:1.8 from top to bottom. b) Normalized abundance of each species calculated from the mass spectra during the titration. The experimental speciation was fitted by a simulated speciation using Hyperquad Simulation and Speciation (HySS) at the same concentration. From the simulated speciation, HySS provides cumulative $(\beta)$ binding constants for the first $\left(\beta_{1}\right)$ and second $\left(\beta_{2}\right) \mathrm{Cu}(\mathrm{II})$ binding to the peptide. From these cumulative binding constants, the stepwise binding constants $\left(\mathrm{K}_{\mathrm{A}}\right)$ for the first $\left(\mathrm{K}_{1}\right)$ and second $\left(\mathrm{K}_{2}\right) \mathrm{Cu}(\mathrm{II})$ bound to the peptide were determined as $10^{8.95}$ and $10^{8.34}$, respectively.

Additionally, the turnover number (TON), the turnover frequency (TOF), and the maximum yield of $\mathrm{H}_{2} \mathrm{O}_{2}$ dismutation were calculated and are reported in Table 2. The TON is about 3.7 which is slightly weaker than for most MnP but higher than for other $\mathrm{Mn}$ complexes possessing CAT-like activities. ${ }^{46}$ To note, as already reported, the 1:1 complex has been investigated for its SOD activity in cuvette using the Mc Cord and Fridovich assay. ${ }^{52}$ In this assay, the $\mathrm{IC}_{50}$ of the $1: 1$ complex was $372 \mathrm{nM}$ which was only 1.6 time better than $\mathrm{CuSO}_{4}\left(\mathrm{IC}_{50}\right.$ $=603 \mathrm{nM})$. This shows that this complex has a very weak SOD activity. This illustrates that the strategy allowed for the selection of an efficacious catalyst for the targeted activity only.

Table 2. Parameters describing the catalysis of $\mathrm{H}_{2} \mathrm{O}_{2}$ dismutation in MOPS $(50 \mathrm{mM}, \mathrm{pH}$ $7.5,25^{\circ} \mathrm{C}$ ): $k_{\text {cat }}$ the initial rates of $\mathrm{O}_{2}$ formation, the end point (maximum amount of $\mathrm{O}_{2}$ formed), the TON (turnover number), $\mathrm{O}_{2}$ yield and TOF (turnover frequency).

\begin{tabular}{|c|c|c|c|c|c|c|}
\hline & $\begin{array}{c}k_{\text {cat }} \\
\left(\mathrm{M}^{-1} \cdot \mathrm{s}^{-1}\right)\end{array}$ & $\begin{array}{c}\mathrm{v}_{0} \\
\left(\mu \mathrm{M} \cdot \mathrm{s}^{-1}\right)\end{array}$ & $\begin{array}{c}\text { End } \\
\text { Point }{ }^{[a]}\end{array}$ & TON & $\begin{array}{c}\text { Yield }^{[b]} \\
(\%)\end{array}$ & $\begin{array}{c}\text { TOF }^{[c]} \\
\left(\mathrm{s}^{-1}\right)\end{array}$ \\
\hline \multicolumn{7}{|c|}{ CATm1:Cu(II) $(50 \mu \mathrm{M})$} \\
\hline $1: 1^{[\mathrm{d}]}$ & 0.52 & 0.12 & 146 & 2.9 & 5.8 & 0.002 \\
\hline $1: 2$ & 5.12 & 1.17 & 187 & 3.7 & 6.7 & 0.023 \\
\hline \multicolumn{7}{|c|}{$\mathrm{Cu}(\mathrm{OAc})_{2}(100 \mu \mathrm{M})$} \\
\hline & 2.08 & 0.56 & 272 & 2.7 & 10.9 & 0.006 \\
\hline \multicolumn{7}{|c|}{ Catalase (1 nM) } \\
\hline & $4.510^{5}$ & 0.80 & 396 & $410^{5}$ & 15.9 & 800 \\
\hline
\end{tabular}

[a] $\left(\max , \mu \mathrm{M} \mathrm{O}_{2}\right)$. [b] Yield of $\mathrm{O}_{2}$. [c] Based on initial rate. [d] In sodium phosphate $\left(50 \mathrm{mM}, 25^{\circ} \mathrm{C}\right)$ at $\mathrm{pH} 7.5$.

To go further, this new catalyst was assayed on HeLa cells which express the protein HyPer intracellularly. HyPer is a genetically encoded ratiometric fluorescent sensor of $\mathrm{H}_{2} \mathrm{O}_{2}$ based on a circularly permuted yellow fluorescent protein (cpYFP) integrated into the regulatory domain of the bacterial $\mathrm{H}_{2} \mathrm{O}_{2}$ sensing protein OxyR (OxyR-RD). ${ }^{71}$ In presence of $\mathrm{H}_{2} \mathrm{O}_{2}$, thiols of HyPer are oxidized, leading to the formation of disulfide bridges that modify the conformation of the protein and thus its spectral properties. The ratiometric modification of the excitation spectrum of HyPer can consequently allow monitoring $\mathrm{H}_{2} \mathrm{O}_{2}$ levels by measuring the ratio

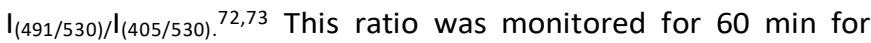
several cells (typically 10 to 25 cells) before and after addition of CATm1:Cu 1:1 or 1:2 mixtures at $250 \mu \mathrm{M}$ and the corresponding controls (CATm1 at $250 \mu \mathrm{M}$, or $\mathrm{CuSO}_{4}$ at $500 \mu \mathrm{M}$ ) in MOPS buffer ( $30 \mathrm{mM}, \mathrm{pH}$ 7.5). To note, no additional $\mathrm{H}_{2} \mathrm{O}_{2}$ was added, the observed effects are thus modifications of the basal level of $\mathrm{H}_{2} \mathrm{O}_{2}$. Since $\mathrm{H}_{2} \mathrm{O}_{2}$ is mainly produced at the membranes and can easily diffuse through, ${ }^{74}$ an efficient catalase mimic that remains outside the cells may induce a decrease of the $\mathrm{H}_{2} \mathrm{O}_{2}$ concentration inside the cells. This is the case of HeLa HyPer cells incubated with catalase that does not translocate into cells but leads to a fluorescence ratio decrease. ${ }^{75}$ The intensity ratios $\left(I_{(491 / 530)} / I_{(405 / 530)}\right)$ normalized against the values from the cells before the addition of the tested compounds are reported in Fig. 5. As shown in Fig. 5, the $\mathrm{H}_{2} \mathrm{O}_{2}$ concentration decreased rapidly after addition of the $1: 2$ complex and was then stabilized around $28 \%$ after $40 \mathrm{~min}$. The same trend was observed for the 1:1 ratio, but to a lesser extent than for the 1:2 ratio. For the CATm1 peptide alone, a slight decrease of the fluorescence ratio was also observed, but after 20 min the $\mathrm{H}_{2} \mathrm{O}_{2}$ concentration increased to the initial level. Addition of copper salt led to a decrease of the $\mathrm{H}_{2} \mathrm{O}_{2}$ concentration, but only by $19 \%$. 


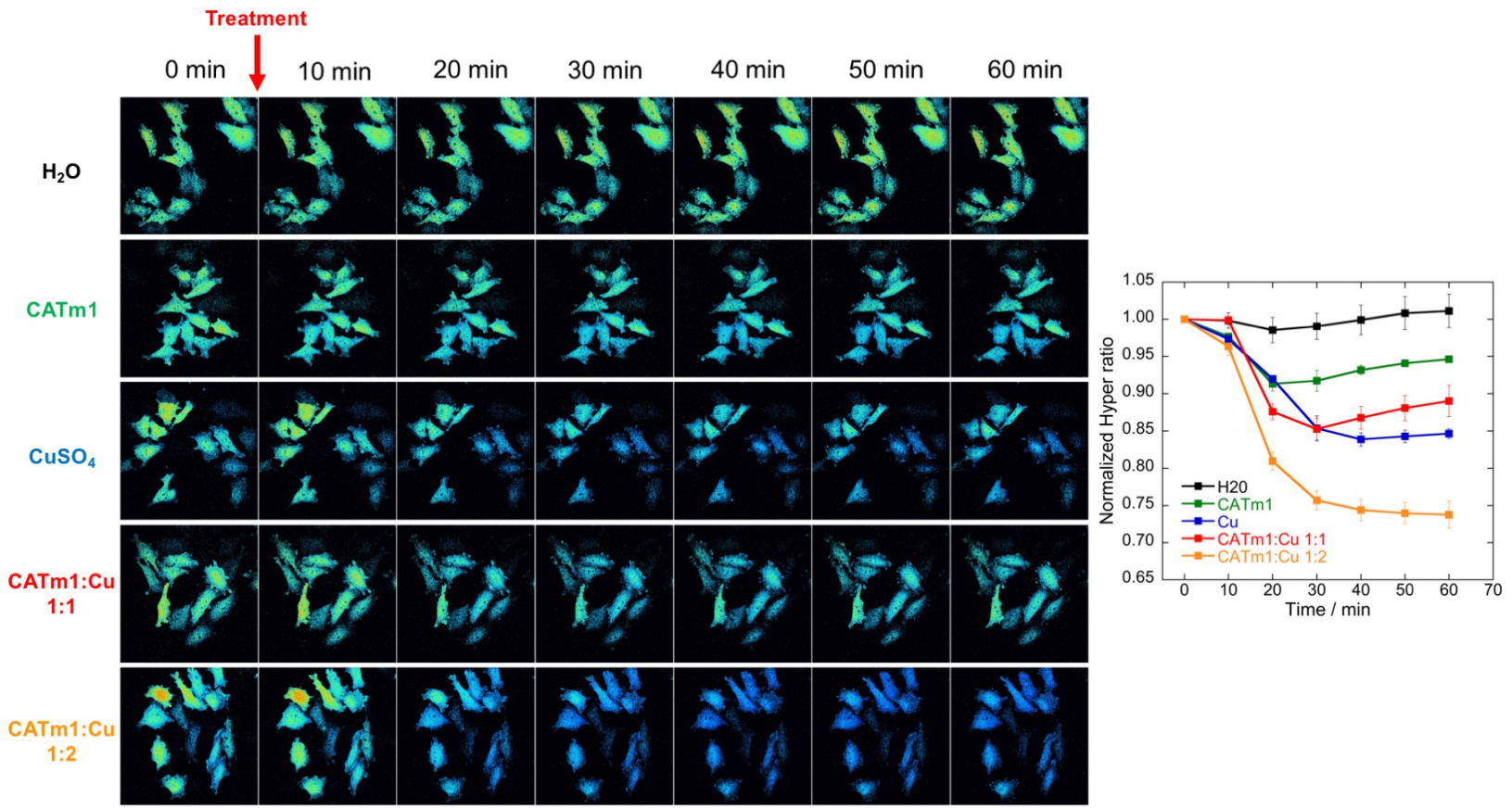

Fig. $5 \mathrm{H}_{2} \mathrm{O}_{2}$ levels in Hela Hyper cells monitored by fluorescence for 60 min after treatment with $\mathrm{H}_{2} \mathrm{O}$ (control cells), CATm1 peptide (250 $\mu \mathrm{M}$ ), CuSO ${ }_{4}(500 \mu \mathrm{M})$, complex $\mathrm{CATm} 1-\mathrm{Cu} \mathrm{u}^{2+}$ 1:1 $(250 \mu \mathrm{M})$ or complex CATm1-Cu2 $1: 2(250 \mu \mathrm{M})$. The right panel represents the mean of the ratio for 2 or 3 independent experiments.

Significantly, these data strongly support the fact the $1: 2$ complex is the most efficient species for $\mathrm{H}_{2} \mathrm{O}_{2}$ dismutation in cells.

\section{Conclusion}

In conclusion, this innovative strategy combining a combinatorial approach with an activity-based screening of the peptidyl metal complexes library led to the discovery of an efficacious di-Cu(II) complex with CAT activity. As far as we know, this is the first peptidyl complex mimicking the anti-oxidant properties of CAT reported so far. Its characterization was performed using a range of techniques (DC, ITC, CV, and ESI-MS), and its activity was determined in vitro using a Clark electrode and in a cellular assay. The cellular assay results are very encouraging as many potential metal ligands exist in the cell culture media that could have competed with the peptide and could have led to its destruction. The biological activity of this class of complexes may be improved if a higher stability could be achieved and work towards this goal is currently in progress in the lab.

\section{Experimental section}

\section{General}

All chemicals and solvents were of synthesis grade and were used as received without further purification. Common solvents for solid support synthesis and L-amino acids were obtained from either Sigma Aldrich, Novabiochem or Iris biotech GMBH. CATm1 peptide was synthesized on an Advanced ChemTech automated synthesizer at the IBPS SU, FR3631 peptide synthesis core facility and purified by HPLC as described.

MALDI-TOF mass spectra were recorded on a Voyager DE-Pro MALDI-TOF mass spectrometer (Applied Biosystems) in positive mode using as matrix a solution of $\alpha$-Cyano-4-hydroxycinnamic acid (CHCA) at $10 \mathrm{mg} / \mathrm{mL}$ in $\mathrm{CH}_{3} \mathrm{CN}: \mathrm{H}_{2} \mathrm{O}$ (50:50) containing $0.1 \%$ TFA. Calibration was performed using external standards (Proteomix 4, LaserBio Labs Sofia-Antipolis, France). Electrospray ionization mass spectrometry was performed on a Bruker MicrOTOF II with the following parameters: capillary voltage $=4200 \mathrm{~V}$, Nebulizer $=2.0$ Bar, Dry gas $=4.0 \mathrm{~L} / \mathrm{min}$, Dry Temp $=200{ }^{\circ} \mathrm{C}$, Capillary exit voltage $=100 \mathrm{~V}$. Analytical HPLC was performed on an Agilent Technologies 1200 Series equipped with a multiple wavelength absorbance detector, using a Proto $200 \mathrm{C} 183 \mu \mathrm{m}$ Higgins Analytical Inc. $100 \times 4.6 \mathrm{~mm}$ column. Preparative HPLC was performed on a Waters 600 HPLC Pump equipped with a Waters 2487 dual wavelength absorbance detector, using a Column VP 260/16 C18 Htec $5 \mu \mathrm{m}$. UV-vis spectrometry was performed on a Cary 300 bio in a double beam mode with the buffer in the reference cell at $25^{\circ} \mathrm{C}$. Electron Paramagnetic Resonance (EPR) data were recorded using an Elexsys E500 Bruker spectrometer, operating at a microwave frequency of approximately $9.44 \mathrm{GHz}$. Spectra were recorded using a microwave power of $20 \mathrm{~mW}$ across a sweep width of $250 \mathrm{mT}$ (centered at $310 \mathrm{mT}$ ) with modulation amplitude of $0.5 \mathrm{mT}$. Experiments were carried out at $110 \mathrm{~K}$ using a liquid nitrogen cryostat. Circular dichroism (CD) spectra (215-300 $\mathrm{nm})$ were collected on a J-810 spectropolarimeter (Jasco, Tokyo, Japan). Cyclic Voltammetry measurement were performed using a MetrOhm potentiostat (AUTOLAB model). All measurements were carried out in the indicated buffer. Glassy carbon (GC), a platinum plate and SCE KCl saturated were used as working electrode, counter and reference electrode, respectively; all potential values are reported versus NHE reference. Isothermal titration calorimetry (ITC) experiments were performed on a TA Instrument (New Castle, DE) NanolTC calorimeter and analyzed using the provided software. The ability of the complex to catalyze $\mathrm{H}_{2} \mathrm{O}_{2}$ dismutation was 
measured by polarography. An $\mathrm{O}_{2}$-sensitive Clark-type electrode OD InLab 605-ISM purchased from Mettler Toledo was used. Prior to measurements, the electrode was calibrated in ambient air then in a provided $0 \%$ dissolved oxygen solution.

\section{Procedures and data analysis}

\section{Peptide library synthesis on solid support (Fig. S1)}

Linkers coupling and first amino acid grafting. The peptides library was synthesized manually on solid support by using standard Fmoc chemistry on 1 gram of Tentagel macrobeads (loading: $0.24 \mathrm{mmol} / \mathrm{g}, 280-300 \mu \mathrm{m}$ ). First, orthogonal linkers (6 equiv.) coupling was performed on a solution of HMBA and 3N-Fmoc-amino-3-(2-nitrophenyl)propionic acid (Fmoc - ANP) linkers (10:1) with HOBT (1 equiv.) and DIC (1 equiv.) in DMF for 1h. Standard deprotection conditions of Fmoc group were employed (20\% piperidine in DMF for $1 \mathrm{~min}$ then $10 \mathrm{~min}$ at room temperature) followed by washings with NMP. Then the first amino acid was introduced by treatment with the symmetrical anhydride of BAla (6 equiv.) in the presence of 4dimethylaminopyridine ( 0.1 equiv.) in DMF for $1 \mathrm{~h}$.

Amino acid coupling reactions (without capping). Coupling reactions were performed in NMP $(3 \mathrm{~mL}$ ) with HOBT (3 equiv.) and HBTU ( 3 equiv.) as coupling agents and in basic conditions (diisopropylethylamine, DIEA, 6 equiv.). The resin was shaken for 45 to $60 \mathrm{~min}$ at room temperature. After each reaction, solvents and soluble reagents were removed under vacuum and the resin was washed 5 times with NMP. Completion of the reaction was monitored by the Kaiser test, which indicates the presence of free amine by a blue coloration of the bead. The amino acid coupling was repeated as many times as necessary until a negative test Kaiser was obtained. Then, Standard deprotection conditions of Fmoc group were employed $(20 \%$ piperidine in DMF for $1 \mathrm{~min}$ then $10 \mathrm{~min}$ at room temperature) followed by washings with NMP $(5 \times 3 \mathrm{~mL})$.

Amino acid coupling reactions (with capping). By using Bibilo software, the positions in the library that required capping were identified, then manual calculation of truncated peptide molar mass allowed for the determination of which commercially available capping reagent combination was required to obtain a non-degenerate mass ladder. The twelfth coupling required simultaneous capping since it is a mass encoding step. Coupling then involved treatment with a mixture of the desired amino acid and mass cap (85:15, 10 equiv.), N,N diisopropylcarbodiimide (DIC), and $\mathrm{N}$-hydroxybenotriazole (HOBt) in 10:10 ratio in DMF for 1 hour. The mass caps were: BocD for $\mathrm{E}$, BocW for $\mathrm{H}$, BocF for $\mathrm{Y}$, Bocl for R and BocA for $\mathrm{G}$.

Split and pool strategy. The ninth, twelfth and the thirteenth coupling were performed after splitting the resin. The resin was split into 5 approximately equal portions. Then, each batch reacted with a different amino acid using standard coupling

conditions. After the reaction, all five batches were pooled together and the next coupling was performed.

A final acetylation was performed on the last amino acid (Proline) by a solution of acetic anhydride in dichloromethane (DCM) (3 mL, 10/90 v:v) for $1 \mathrm{~h}$ at room temperature. Solvents and soluble reagents were removed by filtration. The resin was washed with DCM $(5 \times 3 \mathrm{~mL})$ then by methanol $(3 \times 3 \mathrm{~mL})$. The resin was dried under vacuum for 1 h. Finally, deprotection of the lateral chains was carried out in acidic conditions with TFA/ $\mathrm{H}_{2} \mathrm{O} /$ Trisopropylsilane $(95 \% / 2.5 \% / 2.5 \%)$ for $2 \mathrm{~h}$ at room temperature. The resin was then washed sequentially by TFA, DCM and HEPES buffer.

\section{Complexes formation}

Beads (ca. $50 \mathrm{mg}$ ) were inserted in PP syringe with a frit and were washed with HEPES $(50 \mathrm{mM}, \mathrm{pH} 7.5)$ solution $(3 \times 1 \mathrm{~mL})$. The beads were incubated for $2 \mathrm{~h}$ at $60^{\circ} \mathrm{C}$ with $2 \mathrm{~mL}$ of a $\mathrm{Cu}(\mathrm{OAc})_{2}$ solution $(10 \mathrm{mM})$ in HEPES $(50 \mathrm{mM}, \mathrm{pH} 7.5)$. After incubation, the solution was removed by filtration and the beads were washed with HEPES ( $50 \mathrm{mM}, \mathrm{pH} 7.5,1 \times 1 \mathrm{~mL}$ ), EDTA $(25 \mathrm{mM}, 1 \mathrm{~min}, 1 \times 1 \mathrm{~mL}$ ) then again with HEPES (50 mM, pH $7.5,3 \times 1 \mathrm{~mL}$ ) solution to increase the selectivity pressure.

\section{Combinatorial screening and selection}

The beads (approximatively 50-100) were introduced in a small beaker and molten agarose ( $10 \mathrm{~mL}, 2 \%$ in HEPES $50 \mathrm{mM}, \mathrm{pH} 7.5$ ) was added. The solution was poured into a Petri dish, so that the beads were evenly distributed in the dish. The solution was kept at room temperature for 10 minutes to allow the formation of a gel. The agarose gel was then placed under a UV lamp (electronic dual light transilluminator) at $254 \mathrm{~nm}$ during 10-15 min to cleave the photocleavable linker. The gel was then incubated with a $\mathrm{H}_{2} \mathrm{O}_{2}$ solution ( $10 \mathrm{~mL}, 0.015 \%, 10 \mathrm{~min}$ ) then rinsed extensively with $\mathrm{H}_{2} \mathrm{O}$ milliQ. The water was poured off. A $2 \% \mathrm{FeCl}_{3}$ solution ( $0.6 \mathrm{mg}$ in $30 \mathrm{~mL} \mathrm{H} \mathrm{H}_{2} \mathrm{O}$ milliQ) and a $2 \%$ potassium ferricyanide solution ( $0.6 \mathrm{mg}$ in $30 \mathrm{~mL} \mathrm{H}_{2} \mathrm{O}$ milliQ) were poured together directly on top of the gel. The solution became blue and the gel was incubated for 3 minutes then extensively washed by $\mathrm{H}_{2} \mathrm{O}$ milliQ. Beads with white halos were cut from the agarose gel with a tip of a $1 \mathrm{~mL}$ pipette and transferred to a $1.5 \mathrm{~mL}$ eppendorf tube. The residual agarose surrounding the selected bead was melted away in distilled $\mathrm{H}_{2} \mathrm{O}$ $(1 \mathrm{~mL})$ at $110^{\circ} \mathrm{C}$. The selected bead was subsequently washed with ethylenediaminetetraacetate $(0.5 \mathrm{M} ; \mathrm{pH}$ 7.0), then extensively with $\mathrm{H}_{2} \mathrm{O}$ for the metal decoordination. Peptides were cleaved from the bead by treatment with $\mathrm{NH}_{4} \mathrm{OH}$ (28\%, 50 $\mu \mathrm{L}$ ) overnight at room temperature. After cleavage, the solution was freeze-dried, and the peptide residue resuspended in an $\mathrm{H}_{2} \mathrm{O}$ milliQ $(100 \mu \mathrm{L})$ as a library stock solution.

\section{Sequence determination by MALDI-TOF mass spectrometry}

$1 \mu \mathrm{L}$ of peptide stock solutions was mixed with $1 \mu \mathrm{L}$ of matrix solution and $1 \mu \mathrm{L}$ of the mixture solution was placed onto the MALDI plate and allowed to crystallize. Peptides sequencing was carried out with the Software developed by C. Griesinger et al. ${ }^{59}$ ( Fig. S4).

\section{CATm1 purification}

The peptide was purified by reverse phase HPLC on a VP260/16 semipreparative column with a linear gradient from 5 to $30 \%$ acetonitrile in water both containing $0.1 \%$ TFA over $30 \mathrm{~min}$. High purity (> 95\%) was confirmed by analytical HPLC (Proto $200 \mathrm{C} 18$ column from $5 \%$ to $100 \%$ acetonitrile in water and $0.1 \%$ TFA over $10 \mathrm{~min}$ ) and the expected mass was found by MALDI-TOF mass spectrometry: $[\mathrm{M}+\mathrm{H}]^{+}=1128.4$ (Fig. S2 and S3). 


\section{Peptide stock solution preparation}

Stock solution of the peptide was prepared by dissolving peptide powder in milliQ water. Stock solution concentration was determined by measuring the UV-vis spectrum of a diluted solution ( $1 \mu \mathrm{l}$ in $449 \mu \mathrm{l}$ of milliQ water) and using the extinction coefficient of the tyrosine Tyr considered as free tyrosine $\left(\varepsilon_{276}\right.$ $\left.=1280 \mathrm{~cm}^{-1} \mathrm{M}^{-1}\right)$.

\section{Electron Paramagnetic Resonance spectroscopy (EPR)}

EPR experiments were carried out at $110 \mathrm{~K}$ using liquid nitrogen cryostat. EPR samples $(200 \mu \mathrm{l})$ were prepared from stock solution of peptide diluted down to $0.2 \mathrm{mM}$ in MOPS buffer ( 0.5 $\mathrm{M}, \mathrm{pH}$ 7.5). $\mathrm{Cu}^{2+}$ was added from $50 \mathrm{mM}$ stock solution of $\mathrm{CuSO}_{4}$ in water to form the complexes. Samples were frozen in an ethanol/liquid nitrogen solution in quartz tube after addition of $10 \%$ glycerol as a cryoprotectant and stored in liquid nitrogen until used.

\section{Titration by circular dichroism (CD)}

Spectra of solutions of Catm1 (200 $\mu \mathrm{M})$ in MOPS buffer $(50 \mathrm{mM}$, $\mathrm{pH}$ 7.5) were recorded before and after successive additions of $\mathrm{CuSO}_{4}$. A $1 \mathrm{~mm}$ cell was used and the spectra were recorded with a Peltier temperature controller set at $298 \mathrm{~K}$ under constant nitrogen flush. The wavelength range was set from 300 $\mathrm{nm}$ to $215 \mathrm{~nm}$. The scan rate, the sensitivity, and bandwidth were respectively $200 \mathrm{~nm} \cdot \mathrm{min}^{-1}, 0.125 \mathrm{~s}$, and $1 \mathrm{~nm}$. Each spectrum was an average of three scans.

\section{Cyclic voltammetry experiments}

All measurements were carried out in a buffer (MOPS or TRIS at $\mathrm{pH} 7.5$ or 7). Glassy carbon (GC), a platinum plate and SCE KCl saturated were used as the working electrode, counter and reference electrode, respectively. All potential values are reported versus the SCE reference electrode. Dissolved dioxygen was removed by bubbling the solution with dinitrogen gas. Between each measurement the working electrode was washed with distilled water and polished with sand paper.

\section{Isothermal titration calorimetry (ITC)}

Titration at pH 7: titrations were performed by injecting $10 \mu \mathrm{L}$ aliquots of $5 \mathrm{mM} \mathrm{CuSO}_{4}$ into the calorimeter cell containing the peptide CATm1 solution ( $0.5 \mathrm{mM}$ ) diluted in MOPS buffer (50 $\mathrm{mM}$; pH 7), with $10 \mathrm{~min}$ between two injections. The experiments were performed at $25{ }^{\circ} \mathrm{C}$. Data were analyzed using the program NanoAnalyze provided by TA Instruments.

\section{Titration by electrospray ionization mass spectrometry}

$1 \mathrm{mM} \mathrm{Cu}(\mathrm{OAc})_{2} \bullet \mathrm{H}_{2} \mathrm{O}$ was titrated into $20 \mu \mathrm{M}$ CATm1 peptide solution in a $10 \mathrm{mM}$ ammonium formate solution at $\mathrm{pH}$ 7.5. After each addition of $\mathrm{Cu}(\mathrm{II})$, the sample was measured using electrospray ionization mass spectrometry. The abundance of apo CATm1, CATm1-Cu $\mathrm{Cu}_{1}$, and CATm1-Cu $\mathrm{Cu}_{2}$ were normalized from each step in the ESI-MS titration. The amount of $\mathrm{Cu}(\mathrm{II})$ bound was calculated from the mass spectra to generate the speciation as a function of $\mathrm{Cu}(\mathrm{II})$ added. This speciation was simulated using Hyperquad Simulation and Speciation (HySS). The same concentrations of peptide and $\mathrm{Cu}(\mathrm{II})$ as the experimental data were used in the HySS simulation. 2.0 mol. eq. of $\mathrm{Cu}(\mathrm{II})$ were added in the simulated titration. HySS uses cumulative $(\beta)$ binding constants and the simulated cumulative constant for the first $\left(\beta_{1}\right)$ and second $\left(\beta_{2}\right) \mathrm{Cu}(\mathrm{II})$ binding to the peptide were adjusted until the simulation fit the experimental data. From these cumulative binding constants, the stepwise binding constants for the first $\left(\mathrm{K}_{1}\right)$ and second $\left(\mathrm{K}_{2}\right) \mathrm{Cu}(\mathrm{II})$ bound to the peptide were found to be 8.95 and 8.34 , respectively.

\section{Catalase activity assay using a Clark-type electrode}

The experiments were carried out in MOPS buffer $(0.1 \mathrm{M}, \mathrm{pH}$ 7.5) in a micro cell sealed with a rubber septum to avoid the introduction of $\mathrm{O}_{2}$ from the air. The dissolved dioxygen was removed by bubbling the solution with dinitrogen gas. Hydrogen peroxide solution $(15 \%, 1 \mu \mathrm{l}$ ) was added. The dioxygen from the spontaneous dismutation of hydrogen peroxide was removed by bubbling the solution with dinitrogen gas. Finally, sample was injected through the septum to the stirred $\mathrm{H}_{2} \mathrm{O}_{2}$ solution. Reaction rates were determined by measurement of the $\mathrm{O}_{2}$ evolved upon time as described in reference. ${ }^{46}$ The initial rates $v_{0}$ were measured from the initial slope of dioxygen formation at several complex concentrations $\left(50,100,150,200\right.$ and $250 \mu \mathrm{M}$. Then $k_{o b s}$ corresponds to the slope of the linear fit of $\mathrm{v}_{0}=\mathrm{f}$ [catalyst] (Fig. S7). The apparent second-order rate constant in $\mathrm{M}^{-1} \mathrm{~s}^{-1}\left(k_{\text {cat }}\right)$ were determined from $k_{o b s}$ since $\left[\mathrm{H}_{2} \mathrm{O}_{2}\right]=2\left[\mathrm{O}_{2}\right] ; k_{c a t}=2 k_{\text {obs }} /\left[\mathrm{H}_{2} \mathrm{O}_{2}\right]_{0}$.

Complementary kinetics parameters were determined at $50 \mu \mathrm{M}$ of the catalysts in $5 \mathrm{mM} \mathrm{H}_{2} \mathrm{O}_{2}$ solution in MOPS $(50 \mathrm{mM})$ at $\mathrm{pH}$ 7.5. The maximal yield of $\mathrm{O}_{2}$ production (in \%) was calculated from the measured $\left[\mathrm{O}_{2}\right]_{\max }$ obs values using the following equation: Yield $\mathrm{O}_{2}(\%)=\left(2\left[\mathrm{O}_{2}\right]_{\max \text { obs }} /\left[\mathrm{H}_{2} \mathrm{O}_{2}\right]_{0}\right) \times 100$. The TON was calculated as maximal number of $\mathrm{O}_{2}$ moles produced per mole of a catalyst, TON $=\left[\mathrm{O}_{2}\right]_{\max \text { obs }} /$ [Catalyst $]_{0}$. The TOF values in $\mathrm{s}^{-}$ ${ }^{1}$ which represents the ratios of initial rates per concentrations of catalysts was calculated as followed: $\mathrm{TOF}=\mathrm{v}_{0} /[\text { Catalyst }]_{0}$

\section{Experiments on HeLa HyPer cells}

Cell culture. Stable cell line HeLa HyPer1 was prepared using the HeLa Flp-In cell line, which was kindly provided by Stephen Taylor ${ }^{76}$ and cultured at $37^{\circ} \mathrm{C}$ under a $5 \% \mathrm{CO}_{2}$ atmosphere. HyPer1 expression in this stable cell line was controlled by doxycycline, added $24 \mathrm{~h}$ after seeding. The cells were cultured for an additional $24 \mathrm{~h}$ before being processed for analysis.

Pharmacological treatments. Cells were incubated with or without antioxidant during $1 \mathrm{hr}$ at $37^{\circ} \mathrm{C}$ under a $5 \% \quad \mathrm{CO}_{2}$ atmosphere.

Imaging. Imaging was performed with a CSU-W1 Yokogawa spinning disk coupled to a Zeiss Axio Observer Z1 inverted microscope equipped with a SCMOS Hamamatsu camera and a $63 \times$ objective (63 $/ 1.4$ oil WD: $0.17 \mathrm{~mm}$ ) oil objective. DPSS 100 $\mathrm{mW} 405 \mathrm{~nm}$ and $150 \mathrm{~mW} 491 \mathrm{~nm}$ lasers and a 525/50 bandpass emission filter were used.

$\mathrm{H}_{2} \mathrm{O}_{2}$ levels quantification and statistical analysis. Images were processed with the Fiji software, to obtain the HyPer1 ratio of the emission at $530 \mathrm{~nm}(491 / 530) /(405 / 530)$. HyPer ratio was then measured for several cells, and normalized to the ratio value of the control condition. Data were analyzed using GraphPad Prism 8 and expressed as the mean \pm standard error of the mean (SEM). Statistical significance was calculated using 
an ordinary one-way ANOVA followed by Tukey's multiple comparison test.

\section{Conflicts of interest}

"There are no conflicts to declare".

\section{Acknowledgements}

The authors thank Carole Aimé (and the LCMCP), Sandrine Sagan et Sonia Lajnef for their help with the circular dichroism, Isothermal Titration Calorimetry and Electron Paramagnetic Resonance experiments respectively. We thank the IBPS SU, FR3631 mass spectrometry and peptide synthesis core facilities for access to the MALDI-TOF spectrometer and for providing us peptides respectively. Frédéric Lemaître and Manon Guille are gratefully acknowledged for their help with the electrochemistry experiments. This work was funded by the ANR grant 16-CE07-0025-01. Work was also funded by NSERC of Canada through Discovery Grant 2020-06545 to M. J. S. and a Canada Graduate Scholarship to A. M. as well as by a Graduate Entrance Scholarship funded by the University of Western Ontario (A. M.).

\section{Notes and references}

1 W. Dröge, Physiological Reviews, 2002, 82, 47-95.

2 K. M. Holmström and T. Finkel, Nat Rev Mol Cell Biol, 2014, 15, 411-421.

3 H. Sies and D. P. Jones, Nat Rev Mol Cell Biol, 2020, 21, $363-$ 383.

4 H. Sies, C. Berndt and D. P. Jones, Annu. Rev. Biochem., 2017, 86, 715-748.

5 E. Tönnies and E. Trushina, JAD, 2017, 57, 1105-1121.

6 G. Choudhury and W. MacNee, COPD: Journal of Chronic Obstructive Pulmonary Disease, 2017, 14, 122-135.

7 C. J. Murray and A. D. Lopez, The Lancet, 1997, 349, 1498-1504.

8 A. Duni, V. Liakopoulos, K.-P. Rapsomanikis and E. Dounousi, Oxidative Medicine and Cellular Longevity, 2017, 2017, 1-15.

9 A. Y. Putri and M. Thaha, Acta Med Indones, 2014, 46, 9.

10 V. Cachofeiro, M. Goicochea, S. G. de Vinuesa, P. Oubiña, V. Lahera and J. Luño, Kidney International, 2008, 74, S4-S9.

11 N. Bashan, J. Kovsan, I. Kachko, H. Ovadia and A. Rudich, Physiological Reviews, 2009, 89, 27-71.

12 S. Golbidi, S. Alireza Ebadi and I. Laher, $C D R, 2011,7,106-125$.

13 N. Khansari, Y. Shakiba and M. Mahmoudi, IAD, 2009, 3, 73-80.

14 A. Federico, F. Morgillo, C. Tuccillo, F. Ciardiello and C. Loguercio, Int. J. Cancer, 2007, 121, 2381-2386.

15 F. Marc, A. Davin, L. Deglene-Benbrahim, C. Ferrand, M. Baccaunaud and P. Fritsch, Med Sci (Paris), 2004, 20, 458-463.

16 H. Sies, Exp Physiol, 1997, 82, 291-295.

17 J. D. Crapo, T. Oury, C. Rabouille, J. W. Slot and L. Y. Chang, Proceedings of the National Academy of Sciences, 1992, 89, 10405-10409.

18 G. A. Keller, T. G. Warner, K. S. Steimer and R. A. Hallewell, Proceedings of the National Academy of Sciences, 1991, 88, 7381-7385.

19 W. Liou, L. Chang, H. Geuze, G. Strous, J. Crapo and J. Slot, Free Radical Biology and Medicine, 1993, 14, 201-207.

20 L. Y. Chang, The Journal of Cell Biology, 1988, 107, 2169-2179.

21 D. P. Barondeau, C. J. Kassmann, C. K. Bruns, J. A. Tainer and E. D. Getzoff, Biochemistry, 2004, 43, 8038-8047.
22 C. Beauchamp and I. Fridovich, Analytical Biochemistry, 1971, 44, 276-287.

23 L. Britton, D. P. Malinowski and I. Fridovich, 1978, 134, 8.

24 L. Domínguez, A. Sosa-Peinado and W. Hansberg, Archives of Biochemistry and Biophysics, 2010, 500, 82-91.

25 C. Obinger, Archives of Biochemistry and Biophysics, 2012, 525, 93-94.

26 R. Brigelius-Flohé and M. Maiorino, Biochimica et Biophysica Acta (BBA) - General Subjects, 2013, 1830, 3289-3303.

27 S. C. E. Tosatto, V. Bosello, F. Fogolari, P. Mauri, A. Roveri, S. Toppo, L. Flohé, F. Ursini and M. Maiorino, Antioxidants \& Redox Signaling, 2008, 10, 1515-1526.

28 R. Kubota, S. Asayama and H. Kawakami, Journal of Materials Chemistry B, 2019, 7, 3165-3191.

29 M. Genestra, Cellular Signalling, 2007, 19, 1807-1819.

30 J. W. Whittaker, Archives of Biochemistry and Biophysics, 2012, 525, 111-120.

31 M. Alfonso-Prieto, X. Biarnés, P. Vidossich and C. Rovira, Journal of the American Chemical Society, 2009, 131, 1175111761.

32 J. Zhang, Journal of Inorganic Biochemistry, 2001, 86, 573-579.

33 V. V. Barynin, M. M. Whittaker, S. V. Antonyuk, V. S. Lamzin, P. M. Harrison, P. J. Artymiuk and J. W. Whittaker, Structure, 2001, 9, 725-738.

34 T. Poulos, in Biological Inorganic Chemistry, eds. I. Bertini, H. B. Gray, E. I. Stiefel and J. S. Valentine, Universty Science Book: Sausalito, 2007.

35 W. R. Browett and M. J. Stillman, Biochim. Biophys. Acta Prot. Struct., 1980, 623, 21-31.

36 C. D. Putnam, A. S. Arvai, Y. Bourne and J. A. Tainer, Journal of Molecular Biology, 2000, 296, 295-309.

37 M. Alfonso-Prieto, P. Vidossich and C. Rovira, Archives of Biochemistry and Biophysics, 2012, 525, 121-130.

38 S. V. Antonyuk, V. R. Melik-Adamyan, A. N. Popov, V. S. Lamzin, P. D. Hempstead, P. M. Harrison, P. J. Artymyuk and V. V. Barynin, Crystallogr. Rep., 2000, 45, 105-116.

39 G. S. Allgood and J. J. Perry, J. BACTERIOL., 1986, 168, 5.

40 N. I. Jakab, A. Jancsó, T. Gajda, B. Gyurcsik and A. Rockenbauer, Journal of Inorganic Biochemistry, 2008, 102, 1438-1448.

41 J. O. G. Karlsson, L. J. Ignarro, I. Lundström, P. Jynge and T. Almén, Drug Discovery Today, 2015, 20, 411-421.

42 J. Seguí, M. Gironella, M. Sans, S. Granell, F. Gil, M. Gimeno, P. Coronel, J. M. Piqué and J. Panés, Journal of Leukocyte Biology, 2004, 76, 537-544.

43 D. G. Chihichin, V. A. Kotseruba, O. A. Levchenko, G. N. Masanovets, I. I. Seyfullina and G. L. Kamalov, Russian Journal of General Chemistry, 2013, 83, 915-927.

$44 \mathrm{H}$. Sigel, Angewandte Chemie International Edition in English, $1969,8,167-177$.

45 A. E. O. Fisher, S. C. Maxwell and D. P. Naughton, Inorganic Chemistry Communications, 2003, 6, 1205-1208.

46 A. Tovmasyan, C. G. C. Maia, T. Weitner, S. Carballal, R. S. Sampaio, D. Lieb, R. Ghazaryan, I. Ivanovic-Burmazovic, G. Ferrer-Sueta, R. Radi, J. S. Reboucas, I. Spasojevic, L. Benov and I. Batinic-Haberle, Free Radical Biology and Medicine, 2015, 86, 308-321.

47 S. Signorella, C. Palopoli and G. Ledesma, Coordination Chemistry Reviews, 2018, 365, 75-102.

48 S. Signorella and C. Hureau, Coordination Chemistry Reviews, 2012, 256, 1229-1245.

49 U. P. Singh, R. K. Singh, Y. Isogai and Y. Shiro, International Journal of Peptide Research and Therapeutics, 2006, 12, 379385.

50 E. Mathieu, A. E. Tolbert, K. J. Koebke, C. Tard, O. Iranzo, J. E. Penner-Hahn, C. Policar and V. Pecoraro, Chemistry - A European Journal, 2020, 26, 249-258. 
51 G. Csire, S. Timári, J. Asztalos, J. M. Király, M. Kiss and K. Várnagy, Journal of Inorganic Biochemistry, 2017, 177, 198-210.

52 A. Vincent, J. R. Fores, E. Tauziet, E. Quévrain, Á. Dancs, A. Conte-Daban, A.-S. Bernard, P. Pelupessy, K. Coulibaly, P. Seksik, C. Hureau, K. Selmeczi, C. Policar and N. Delsuc, Chem. Commun., 2020, 56, 399-402.

53 V. Solís, C. Palopoli, V. Daier, E. Rivière, F. Collin, D. M. Moreno, C. Hureau and S. Signorella, Journal of Inorganic Biochemistry, 2018, 182, 29-36.

54 M. U. Triller, W.-Y. Hsieh, V. L. Pecoraro, A. Rompel and B. Krebs, Inorganic Chemistry, 2002, 41, 5544-5554.

55 B. K. Shin, M. Kim and J. Han, Polyhedron, 2010, 29, 2560-2568.

56 K. J. Franz, R. L. Maglathlin and B. Imperiali, ChemBioChem, 2003, 4, 272-276.

57 H. Irving and R. J. P. Williams, J. Chem. Soc., 1953, 3192-3210.

58 C. J. Weydert and J. J. Cullen, Nature Protocols, 2010, 5, 51-66.

59 C. Hoffmann, D. Blechschmidt, R. Krüger, M. Karas and C. Griesinger, Journal of Combinatorial Chemistry, 2002, 4, 79-86.

60 R. P. Bonomo, Inorganic Chemistry, 1988, 27, 2510-2512.

61 J. S. Valentine and D. Mota de Freitas, Journal of Chemical Education, 1985, 62, 990.

62 M. W. Pantoliano, J. S. Valentine and L. A. Nafie, Journal of the American Chemical Society, 1982, 104, 6310-6317.

63 J. Peisach and W. E. Blumberg, Archives of Biochemistry and Biophysics, 1974, 165, 691-708.

64 U. Sakaguchi and A. W. Addison, J. Chem. Soc., Dalton Trans., 1979,600

65 K. H. Scheller, T. H. J. Abel, P. E. Polanyi, P. K. Wenk, B. E. Fischer and H. Sigel, European Journal of Biochemistry, 1980, 107, 455-466.

66 H. E. Mash, Y.-P. Chin, L. Sigg, R. Hari and H. Xue, Anal. Chem., 2003, 75, 671-677.

67 E. Boeri Erba and R. Zenobi, Annual Reports Section "C" (Physical Chemistry), 2011, 107, 199-228.

68 J. S. Scheller, G. W. Irvine, D. L. Wong, A. Hartwig and M. J. Stillman, Metallomics, 2017, 9, 447-462.

69 D. B. Ott, A. Hartwig and M. J. Stillman, Metallomics, 2019, 11, 968-981.

70 S. Dong, M. Shirzadeh, L. Fan, A. Laganowsky and D. H. Russell, Anal. Chem., 2020, 92, 8923-8932.

71 V. V. Belousov, A. F. Fradkov, K. A. Lukyanov, D. B. Staroverov, K. S. Shakhbazov, A. V. Terskikh and S. Lukyanov, Nat Methods, 2006, 3, 281-286.

72 N. M. Mishina, K. N. Markvicheva, D. S. Bilan, M. E. Matlashov, M. V. Shirmanova, D. Liebl, C. Schultz, S. Lukyanov and V. V. Belousov, in Methods in Enzymology, eds. E. Cadenas and L. Packer, Academic Press, 2013, vol. 526, pp. 45-59.

73 C. Gauron, F. Meda, E. Dupont, S. Albadri, N. Quenech'Du, E. Ipendey, M. Volovitch, F. Del Bene, A. Joliot, C. Rampon and S. Vriz, Developmental Biology, 2016, 414, 133-141.

74 C. C. Winterbourn, Antioxidants \& Redox Signaling, 2018, 29, $541-551$.

75 I. Amblard, M. Thauvin, C. Rampon, I. Queguiner, V. V. Pak, V. Belousov, A. Prochiantz, M. Volovitch, A. Joliot and S. Vriz, Communications Biology, 2020, 3, 1-9.

76 A. Tighe, O. Staples and S. Taylor, J Cell Biol, 2008, 181, 893901. 